\title{
The genus Triphora (Triphoreae, Orchidaceae) in Colombia
}

\author{
Dariusz L. Szlachetko*, Przemysław Baranow \& Joanna Mytnik-Ejsmont
}

Department of Plant Taxonomy and Nature Conservation, Gdańsk University, Wita Stwosza 59, 80-308 Gdańsk, Poland

* corresponding author (e-mail: dariusz.szlachetko@gmail.com)

\begin{abstract}
In Colombia, four species of Triphora (Orchidaceae) are recognized. Two species (Triphora galeanoi and T. vichadaensis) are newly described. As circumscribed here, the two new species occur exclusively in Colombia apart from T. foldatsii, being known from Colombia and Venezuela, and T. gentianoides, ranging from the USA (Florida) in the north to Colombia in the south. For the species treated, a taxonomic description, synonymy and information about distribution are provided. Additionally, for the two new species, illustrations of flower parts are provided. A key for the determination of the Colombian species of Triphora is included.
\end{abstract}

Key words: new species, Neotropics, taxonomy

\section{Introduction}

The tribe Triphoreae Dressler (Orchidaceae) is a group of small, terrestrial, mycotrophic herbs with fleshy herbaceous stems, plicate or convolute, non-articulated leaves, most often terminal inflorescence and threelobed, basally canaliculate lip with usually distinct longitudinal crests. The group is distributed exclusively in the western hemisphere, in the southern and eastern United States and southern Ontario (Canada) to southeast Brazil. The genera Triphora Nuttall and Psilochilus Barb. Rodr. are the only representatives of the subtribe Triphorinae (Dressler) Szlachetko. In Triphora and Psilochilus, the roots are fleshy and the leaves are scattered along the aerial stem or reduced. The inflorescence is terminal. Considering the gynostemium structure, the representatives of Triphorinae have shelf-like, truncate and erect rostellum without or with rudimentary viscidium (Pansarin \& Amaral 2008; Ferreira et al. 2010) and an anther with fleshy, beak-like apex, set on a prominent filament, stiff to movable. Some authors (i.e. Dressler 1981, 1993; Pridgeon et al. 2005) classify the third genus, Monophyllorchis Schlechter, within the subtribe. This genus is represented by plants with one large, thin leaf and gynostemium with an incumbent anther, rostellum bent forward and collar-like clinandrium.
The members of Triphora are terrestrial, rhizomatous herbs with fleshy roots. Stem is slender, with several, small clasping alternate leaves. The inflorescence is raceme or corymbose, borne in the axils of the uppermost leaves, nodding or erect-spreading, composed of a few small, flowers; sometimes, the inflorescence is reduced to a single flower. The flowers are small, ephemerous, inconspicuous. The gynostemium is elongate, slender, slightly arched or erect in the lower half and then incurved, the column foot is absent, the anther erect, oblong-ellipsoid, motile or immovable with thick connective, more or less elongate apically forming a roof-like structure. There are four oblong and powdery pollinia, no caudiculae, staminodes are completely incorporated into the column part and the stigma is ventral, 3-lobed, confluent, oblong-elliptic to oblong-obovate, flat or more or less concave near the base.

There are twenty one species within the genus Triphora, including Triphora trianthophora (Sw.) Rydberg, the best known species of the group. Most species are inconspicuous in appearance. Due to delicate habit, small size and inconspicuous flowers they are easily overlooked in dense understory of forest, which they usually inhabit. Hence, Triphora collections are poorly represented in most herbaria. The representatives of 
the genus are pollinated by halicitid bees (Pridgeon et al. 2005) and a synchronous blooming strategy may probably enhance the possibility of pollination, however, some species (i.e. T. gentianoides (Sw.) Ames \& Schlechter) are presumed to be self-fertilizing (Dunsterville \& Garay 1965). The name Triphora is derived from the Greek and means "three-bearing", which is probably an allusion to the number of flowers borne on each plant or to the number of crests on the lip (Correll 1978).

The genus ranges widely from eastern North America to subtropical southern Florida and the Caribbean, through Central America and northern South America (Dodson 1992; Garcia Castro et al. 1993; Homoya 1993; Jørgensen \& León-Yánez 1999; Carnevali et al. 2001; Hokche et al. 2008; Martínez Salas et al. 2011) to south Brazil and Argentina (Johnson, A.E. 2001. Las orquídeas del Parque Nacional Iguazú).

Colombia, Ecuador, Peru, and Bolivia cover approximately $2.5 \%$ of the Earth's terrestrial area or $21 \%$ of South America but harbour $12-22 \%$ of the world's flora (Jørgensen et al. 2011). A total of 4,002 vascular plant genera are found in the four countries, 2,944 of which occur in Colombia. The number of vascular plant species found in the country is 24,405 (Jørgensen et al. 2011). Orchids are unique element of the Colombian flora. At present, almost 3,600 orchid species are known from Colombia. Triphora is represented by four species in the country. The main threats to Triphora in Colombia include timber harvest and habitat alteration and collection, what results in changes in canopy composition, changes in light and moisture regimes and disruption of mycoheterotophic relationships.

The taxonomic studies of the Triphoreae as well as the studies of undetermined herbarium material deposited in the Herbarium of Universidad Nacional de Colombia in 2012 revealed that two species of Triphora endemic to Columbia are new to science.

\section{Materials and methods}

The taxonomic studies of the Colombian collection of orchid specimens deposited in Universidad Nacional de Colombia (COL) revealed two new species of Triphora. A standard procedure for the herbarium material was applied. The vegetative and floral characters of individual plants were analyzed. Particular parts of the flower were boiled, dissected, measured and drawn under a binocular microscope. The results were then compared with the type material, diagnoses and original illustrations. The studied specimens were photographed. The database of the studied material is available in the first author's archives. The material from six herbaria (AMES, COL, LD, MEXU, MY, PORT) is cited.

\section{Results}

\section{Triphora Nuttall}

Gen. N. Amer. Pl. 2: 192. 1818. Generitype: Triphora trianthophoros (Sw.) Rydberg

Terrestrial, delicate, small plants with underground, ellipsoid or oblong storage organs. Stem erect, leafy throughout. Leaves decreasing in size up the stem, sessile or sub-petiolate or sessile, blade ovate-cordate or ovate-lanceolate, acuminate, sometimes scale-like. Inflorescence terminal, few-flowered. The lower floral bracts large, leaf-like. Flowers short-lived, pedicellate, rather dull-coloured, whitish or beige. Tepals subsimilar, oblanceolate or linear-lanceolate, more or less spreading. Lip 3-lobed, the basal portion tubular, often with few parallel ridges on the inner surface. Gynostemium elongate, slender, slightly arched or erect, in the lower half and then incurved. Column foot absent. Anther incumbent, oblong-ellipsoid, motile or immovable. Connective thick, rather wide to relatively narrow, more or less elongate apically forming a roof-like structure. Pollinia 4, oblong, powdery. Staminodes absent. Stigma ventral, 3-lobed, confluent, oblong-elliptic to oblongobovate, flat or more or less concave near the base. The middle stigma lobe usually incurved, thickened along apical margin, but no prominent viscidium was observed.

\section{The key to the Colombian species of Triphora}

Leaves scale-like T. gentianoides

- Leaves well-developed with prominent blade .........2

2. Lip obscurely 3-lobed T. vichadaensis

- Lip prominently 3 -lobed .3

3. Lip covered by numerous fleshy projections on the upper surface, lateral lobes oblong-falcate, obtuse T. galeanoi

- Lip not as above T. foldatsii

Triphora vichadaensis Szlach., Baranow \& Mytnik, sp. nov. (Fig. 1).

T. vichadaensis is similar to T. hassleriana, from which it differs by the lip form. The basal part of the lip of new species is oblong-ovate in general outline, the middle lobe is obovate-ligulate with crenulate-undulate margins and with 3 crenulate thickenings along nerves. Hypochile of T. hassleriana is triangular above cuneate base, obscurely 3-lamellate in the centre and sparsely papillose, epichile is obovate with crenulate-undulate margins.

Ty p e : COLOMBIA. Vichada: Comisaria del Vichada, Cano Urimica, en el suelo bajo penumbra, hojas moradas por el enves y flor morada-amarilla por dentro, 22 June 1972, I. Cabrera R. 2339 (holotype: COL!). E t y mology: In reference to the place of origin of the type specimen. 


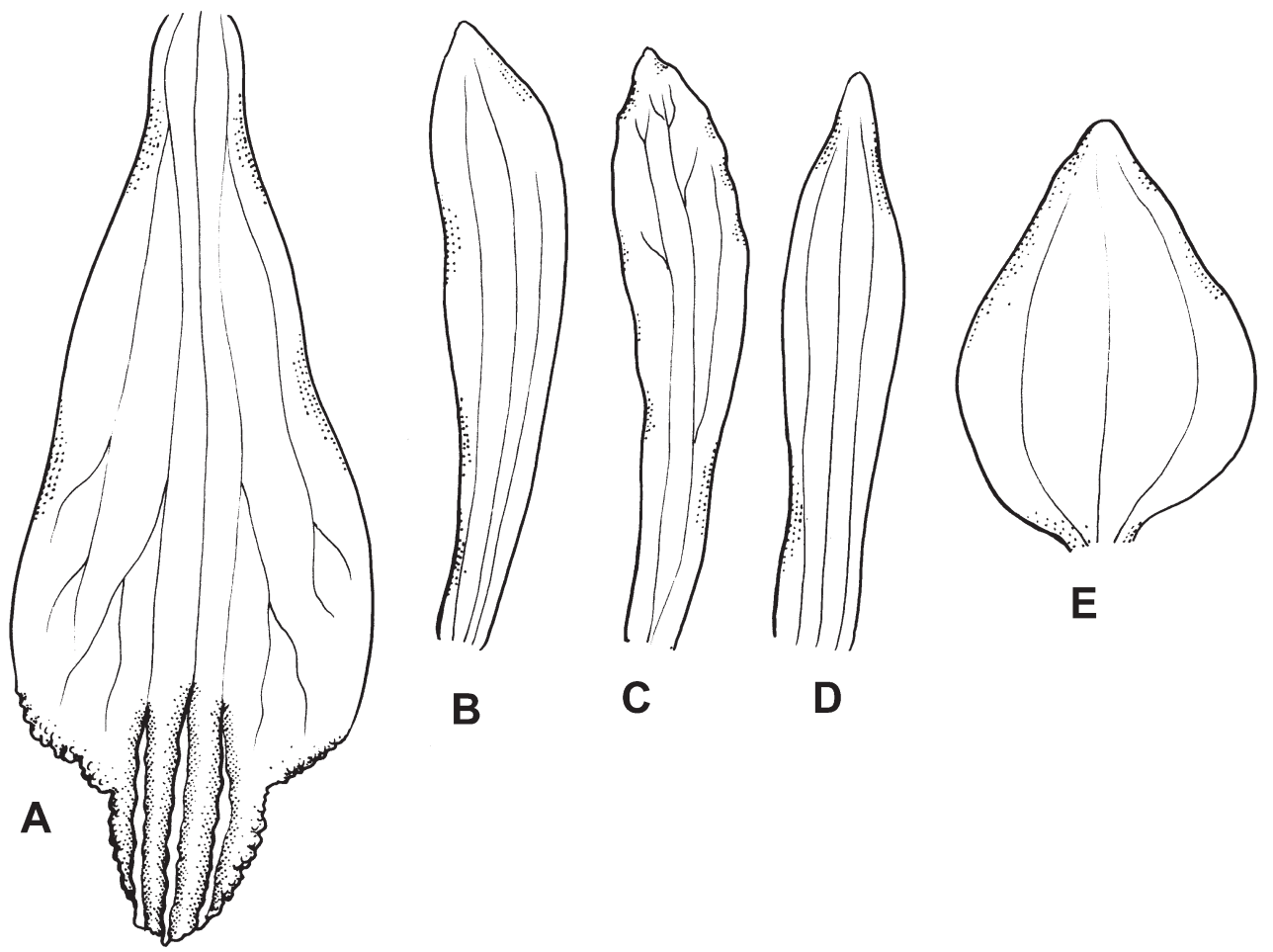

Fig. 1. Triphora vichadaensis Szlach., Baranow \& Mytnik

Explanations: A - lip, B - lateral sepal, C - petal, D - dorsal sepal, E - floral bract (drawn by J. Mytnik-Ejsmont)

Plants to $7 \mathrm{~cm}$ tall, delicate, erect, glabrous. Leaves 2 , up to $1.2 \times 0.8 \mathrm{~cm}$, in the upper part of the stem, broadly ovate, subacute, sessile, with main 3 nerves. Inflorescence single-flowered. Flower small, tubular. Floral bracts to $12 \mathrm{~mm}$ long, leafy. Pedicel and ovary $8 \mathrm{~mm}$ long, slender. Dorsal sepal $10 \times 2 \mathrm{~mm}$, oblongoblanceolate to ligulate-oblanceolate, subacute, concave above the middle, 3 -nerved. Petals $9.5 \times 1.7 \mathrm{~mm}$, linearoblanceolate, subfalcate, subobtuse, apical margins somewhat undulate, nerves 2 , branching. Lateral sepals $9.5 \times 1.8 \mathrm{~mm}$, linear-oblanceolate, subobtuse, subfalcate, 3-nerved. Lip $8.3 \mathrm{~mm}$ long in total; hypochile $7 \times 2 \mathrm{~mm}$ wide, oblong-ovate in general outline, nerves 3-branching; epichile $1.3 \times 0.8 \mathrm{~mm}$, obovate-ligulate with crenulate-undulate margins and with 3 crenulate thickenings along nerves.

Phenology: Flowering in June.

Distribution: The species is known so far from single localization in the Vichada Department in Colombia.

Triphora galeanoi Szlach., Baranow \& Mytnik, sp. nov. (Fig. 2).

The species is similar to Ecuadorian congener T. wagneri. Triphora galeanoi is characterized by some-leaved stem and lip lateral lobes distinctly shorter than middle lobe. Stem of T. wagneri is 1-leaved and lip lateral lobes are as long as epichile. The lip of new species is covered by numerous fleshy projections on the upper surface.

Type: COLOMBIA. Antioquia: Mpio de Cocorna, Vereda la Roca (autopista Medellin-Bogota, km 62), Quebrada La Roca, 2000 m, 3 May 1980, G. Galeano \& R. Bernal 190 (holotype: COL!).

E t y m o log y: Dedicated to G. Galeano, a co-collector of the type specimen.

Plants to $6 \mathrm{~cm}$ tall, very delicate, erect. Leaves 7, distributed along the stem, up to $1 \times 0.7 \mathrm{~cm}$, rhombic-elliptic to suborbicular, acute, subsessile, 3-nerved. Inflorescence laxly 3-4-flowered. Flowers large for the plant size. Floral bracts to $9 \mathrm{~mm}$ long, leafy, acute. Pedicel $8 \mathrm{~mm}$ long. Ovary $5 \mathrm{~mm}$ long. Dorsal sepal $18 \times 3 \mathrm{~mm}$, oblong-lanceolate above linear basal third, subacute, concave above the middle, 3 -nerved. Petals $18 \times 3.5 \mathrm{~mm}$, oblong-linear in the basal two-third, oblong-lanceolate and strongly falcate above, obtuse, nerve 1 , branching. Lateral sepals $18 \times 3.5 \mathrm{~mm}$, oblong-linear in the lower two-third, strongly falcate, ligulate-lanceolate, above, subobtuse, 3-nerved. Lip $18 \mathrm{~mm}$ long, covered on the upper surface by numerous, fleshy projections, especially along 3 main nerves; hypochile triangular above oblong-linear lower half, lateral lobes oblong-falcate, obtuse, distinctly shorter than epichile; epichile $5 \times 6.5-7$ $\mathrm{mm}$, transversely elliptic-subcordate in outline, undulate on margins, obtuse. Gynostemium $17 \mathrm{~mm}$ long. 


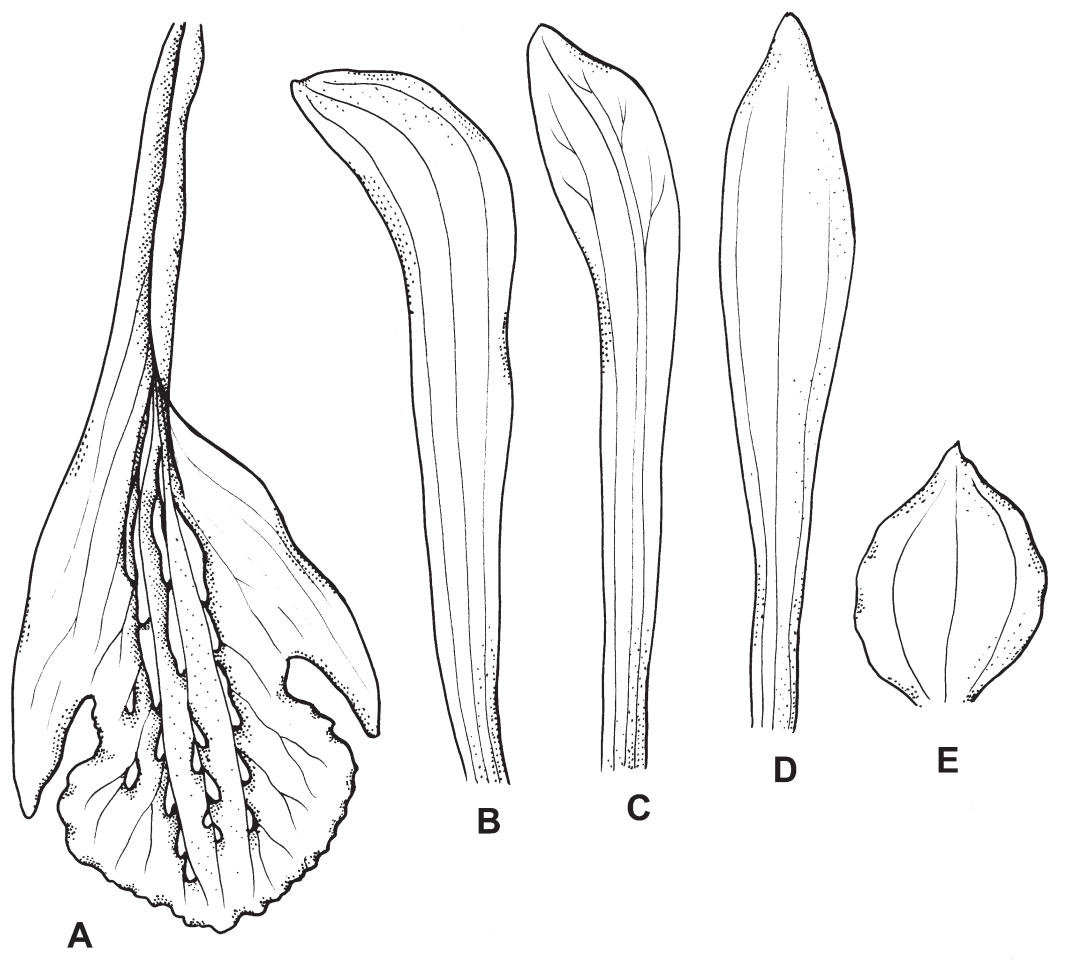

Fig. 2. Triphora galeanoi Szlach., Baranow \& Mytnik

Explanations: A - lip, B - lateral sepal, C - petal, D - dorsal sepal, E - floral bract (drawn by J. Mytnik-Ejsmont)

Phen ology: Flowering in May.

Distribution: The species is known so far from single localization in the Antioquia Department in Colombia.

\section{Triphora foldatsii Carnevali}

Ernstia 22: 10. 1984.

Ty p e : VENEZUELA. Estado Aragua: Dtto. Girardot. Parque Nacional Henry Pittier. Carretera Maracay-Choroni. Alt. 950 m a.s.l. Aug 1981. Carnevali \& Hernandez 1186 (type: MY).

Plants to $11 \mathrm{~cm}$ tall, delicate, glabrous, clustered, usually 2-4 plants growing in clumps. Leaves 2 to 7 distributed along stem, gradually decreasing in size upwards, transforming into floral bracts, 1 or 2 basal sheath-like, usually 2 or 3 normally developed, sessile, up to 0.7 $1.1 \times 0.5-1 \mathrm{~cm}$, transversely elliptic, shortly apiculate, basal sheath cup-like. Inflorescence 1-flowered. Floral bracts to $5 \mathrm{~mm}$ long, elliptic-ovate, apiculate, cup-like. Pedicel to $7 \mathrm{~mm}$ long, very slender, delicate, Ovary to $5 \mathrm{~mm}$ long, glabrous, somewhat pendent. Dorsal sepal $17 \times 1.5 \mathrm{~mm}$, linear-oblanceolate, obtuse, 1-nerved. Petals $18 \times 2.1 \mathrm{~mm}$, linear, subfalcate, subacute. Lateral sepals slightly wider than dorsal sepal, oblanceolateinear, subfalcate, subacute. Lip $16 \times 7 \mathrm{~mm}$ in total, 3 longitudinal nerves prominent; hypochile triangular, lateral lobes acute; epichile $4 \times 4.5 \mathrm{~mm}$, set on prominent claw, suborbicular, truncate at the apex. Gynostemium $13 \mathrm{~mm}$ long.

Phe nology: Flowering in August.

Distribution: Venezuela, Colombia. Alt. 1000$1500 \mathrm{~m}$ a.s.l.

Representative specimens: Colombia. Choco. Bosque al lado derecho del rio Condoto, frente a Condoto. Alt. 70 m a.s.1. 24 Aug. 1955. J.M. Idrobo 1862 (COL!).

Triphora gentianoides (Sw.) Ames \& Schlechter Orchidaceae 7: 5. 1922. $\equiv$ Limodorum gentianoides Sw., Prodr.: 119. 1788.

Ty p e: JAMAICA. Swartz s.n. (type: LD!). $\equiv$ Arethusa gentianoides Sw., Fl. Ind. Occid. 3: 1436. 1806. $\equiv$ Pogonia gentianoides (Sw.) Sprengel, Syst. Veg. 3: 706. 1826.

Plants to $30 \mathrm{~cm}$ tall, relatively stout, erect. Leaves 2 to 6 , up to $1.5 \times 0.9 \mathrm{~cm}$, semiaplexicaul, scale-like. Inflorescence to $10 \mathrm{~cm}$ long, racemose, laxly 3-10-flowered. Flowers erect. Floral bracts $5 \mathrm{~mm}$ long, ovate. Pedicel 8 $\mathrm{mm}$ long, erect, to $70 \mathrm{~mm}$ long after fertilization. Ovary $6 \mathrm{~mm}$ long. Dorsal sepal to $10 \times 10.8 \mathrm{~mm}$, oblong-lanceolate, subacute to subobtuse, 3 -nerved. Petals $8 \times 1.8$ $\mathrm{mm}$, oblong-ligulate, subfalcate, subobtuse, nerves 3 , 
branching. Lateral sepals $9 \times 2 \mathrm{~mm}$, oblong-lanceolate, subfalcate, subacute, 3-nerved. Lip $8.5 \mathrm{~mm}$ long in total, distinctly divided into hypochile and epichile, covered by numerous, clavate projections in the center; hypochile $6 \times 3 \mathrm{~mm}$, broadly ovate above cuneate base, with two crests along lateral nerves, slightly thickened along main nerve, lateral lobes obliquely triangular, acute; epichile $2.6 \times 2.2 \mathrm{~mm}$, elliptic, margins irregularly undulate-crenulate, truncate. Gynostemium $7 \mathrm{~mm}$ long. $\mathrm{Ph}$ e n o log y: Flowering from January to August. D i s tribution: USA(Florida), Honduras, Mexico, Guatemala, el Salvador, Costa Rica, Panama, Ecuador, Venezuela, Colombia.
Representative specimens: Colombia. Dept. Magdalena. Renz 3287 (AMES!). Mexico. Campeche. Mpio. Calakmul. Narciso Mendoza. $16^{\circ} 08^{\prime} 24^{\prime \prime} \mathrm{N}$, $092^{\circ} 46^{\prime} 40^{\prime \prime W}$. Alt. 240 m a.s.1.? 8 Jul 1997. D. Alvarez M. 146 (COL!, MEXU).

Acknowledgements. The authors are grateful to Dr Carlos Parra, the curator of COL for his support during the visits in the herbarium. We wish to thank the anonymous referees whose comments contributed considerably to the improvement of the manuscript. The paper is a part of a project supported with a grant from the Polish Ministry of Science and Higher Education (3930/PO1/2007/33).

\section{References}

Carnevali F. G., Tapia-Muñoz J. L., Jiménez-Machorro R., SÁnChez-SAldaña L., IbarRa-GonzÁlez L., RamíreZ I. M. \& Gómez M. P. 2001. Notes on the flora of the Yucatan Peninsula II: a synopsis of the orchid flora of the Mexican Yucatan Peninsula and a tentative checklist of the Orchidaceae of the Yucatan Peninsula biotic province. Harvard Papers of Botany 5(2): 383-466.

Correll D. S. 1978. Native Orchids of North America North of Mexico. 399 pp. Stanford University Press, Stanford.

Dodson C. H. 1992. Checklist of the Orchids of the Western Hemisphere. Draft manuscript deposited in Missouri Botanical Garden Library.

DRESSLER R. L. 1981. The orchids: natural history and classification. Harvard University Press, Cambridge, Mass.

Dressler R. L. 1993. Phylogeny and Classification of the Orchid Family. Dioscorides Press, Portland, OR.

Dunsterville G. C. K. \& Garay L. A. 1965. Venezuelan Orchids Illustrated, Vol. 3. London, Andre Deutsch Limited.

Ferreira A. W. C., Baptista D. H. \& PAnsarin E. R. 2010. Triphora uniflora (Orchidaceae: Triphorcae): a new species and the first record of the genus Triphora Nutt. for Sao Paulo state, Brazil. Acta Botanica Brasilica 24(1): 288-291.

Garcia Castro J. B., Retana D. E. M. \& Rossi M. E. R. 1993. Lista de orquídeas comunes a Costa Rica y Panama. Brenesia 39-40: 93-107.

Hokche O., Berry P. E. \& Huber O. 2008. Nuevo Catálogo de la Flora Vascular de Venezuela. 859 pp. Fundación Instituto Botánico de Venezuela.
Hомоya M. A. 1993. Orchids of Indiana. 206 pp. Indiana Academy of Science, Bloomington, Indiana, USA.

Johnson A. E. 2001. Las orquídeas del Parque Nacional Iguazú. 282 pp. L.O.L.A. Buenos Aires.

Jørgensen P. M., Ulloa C. U., León B., León-YÁnez S., Beck S. G., Nee M., Zarucchi J. L., Celis M., Bernal R. \& Gradstein R. 2011. Regional Patterns of Vascular Plant Diversity and Endemism. In: S. K. Herzog, R. Martínez, P. M. Jørgensen \& H. Tiessen (eds.). Climate Change and Biodiverstiy in the Tropical Andes, pp. 192-203. Inter-American Institute for Global Change Research (IAI) and Scientific Committee on Problems of the Environment (SCOPE).

Jørgensen P. M. \& León-YÁnez S. 1999. Catalogue of the vascular plants of Ecuador. Monographs in Systematic Botany from the Missouri Botanical Garden 75: $1-1181$

Martínez Salas E. M., Sousa Sánchez M. \& Ramos Álvarez C. H. 2011. Región de Calakmul, Campeche. Listados Floríst. México 22: 1-55.

Pansarin E. R. \& Amaral M. C. E. 2008. Pollen and nectar as a reward in the basal epidendroid Psilochilus modestus (Orchidaceae: Triphoreae): a study of floral morphology, reproductive biology and pollination strategy. Flora 203(6): 474-483.

Pridgeon A. M., Cribb P. J., Chase M. W. \& Rasmussen F. N. 2005. Genera Orchidacearum, vol. 5, Epidendroideae, part 1, 608 pp. Oxford, Oxford University Press. 